\title{
The eye of the crepuscular rodent rock cavy (Kerodon rupestris) (Wied, 1820)
}

\author{
OLIVEIRA, F. G. ${ }^{1}$, ANDRADE-DA-COSTA, B. L. S. ${ }^{2}$, CAVALCANTE, J. S. ${ }^{3}$, \\ SILVA, S. F. ${ }^{4}$, SOARES, J. G. ${ }^{5}$, LIMA, R. R. M. ${ }^{5}$, NASCIMENTO Jr., E. S. ${ }^{5}$, \\ CAVALCANTE, J. C. ${ }^{5}$, RESENDE, N. S. ${ }^{5}$ and COSTA, M. S. M. O. ${ }^{5 *}$
}

\author{
${ }^{1}$ Departamento de Ciências Biológicas, Centro de Ciências Biológicas e da Saúde, \\ Universidade Regional do Cariri - URCA, CEP 63500-000, Crato, CE, Brazil \\ ${ }^{2}$ Departamento de Fisiologia e Farmacologia, Centro de Ciências Biológicas, \\ Universidade Federal de Pernambuco - UFPE, CEP 50670-901, Recife, PE, Brazil \\ ${ }^{3}$ Laboratório de Estudos Neuroquímicos, Departamento de Fisiologia, Centro de Biociências, \\ Universidade Federal do Rio Grande do Norte - UFRN, CEP 59078-900, Natal, RN, Brazil \\ ${ }^{4}$ Departamento de Anatomia, Universidade Potiguar - UNP, CEP 59082-902, Natal, RN, Brazil \\ ${ }^{5}$ Laboratório de Neuroanatomia, Departamento de Morfologia, Centro de Biociências, \\ Universidade Federal do Rio Grande do Norte - UFRN, CEP 59078-900, Natal, RN, Brazil \\ *E-mail: mstela@cb.ufrn.br
}

\begin{abstract}
Introduction: The rock cavy (Kerodon rupestris) is a crepuscular Caviidae rodent belonging to suborder Hystricomorpha, inhabiting semiarid areas of the Brazilian Northeast region. Material and Methods: Previously anesthetized young adult rock cavies were submitted to transcardiac perfusion. The extraocular muscles and components of the eyeball were dissected and measures were taken. Some eyes were embedded in paraffin and sectioned to study the retinal structure. Results: The rock cavy has lateral eyes housed in a well-constituted bony orbit and endowed with well differentiated extrinsic musculature. Descriptive and morphometric anatomical study of the rock cavy eye showed axial diameter mean values of $10.67 \pm 0.55 \mathrm{~mm}$ and an equatorial diameter of $11.64 \pm 0.69 \mathrm{~mm}$. It has a vertical slit pupil and a crystalline lens with a mean axial diameter of $5.4 \pm 0.03$ $\mathrm{mm}$, which corresponds to about $45 \%$ of the eye axial diameter. The posterior nodal distance and the retinal magnification factor were estimated in $6.74 \mathrm{~mm}$ and $118 \mu \mathrm{m} /$ degree, respectively. Conclusion: Anatomical features of the rock cavy eye suggest that it was designed to acquire greater light sensitivity, at the expense of a reduced resolution, compatible with a vision under mesopic conditions, befitting an animal with a pattern of predominantly crepuscular activity.
\end{abstract}

Keywords: eye, orbit, pupil, retina, cavy.

\section{Introduction}

The rock cavy (Kerodon rupestris) is a rodent inhabiting the semiarid Caatinga of the Brazilian Northeast, although it can be also found in the Southeast region as far as the state of Minas Gerais. Colonies of rock cavies usually live in cracks and crevices of granitic rocks, which serve as refuge and shelter from predators (LACHER, 1981). This species reaches adulthood at 200 days, and can reach up to $50 \mathrm{~cm}$ in length and 1 kilogram in body weight (ROBERTS, MALINIAK and DEAL, 1984). According to traditional taxonomy, the rock cavy belongs to the order Rodentia (CARLETON and MUSSER, 2005). According to classifications using the skull shape as a primary characteristic - Anomaluromorpha, Castorimorpha, Hystricomorpha, Myomorpha e Sciuromorpha (CARLETON and MUSSER, 2005), the rock cavy is part of the suborder Hystricomorpha, infraorder Caviomorpha, superfamily Cavioidea, family Caviidae, subfamily Caviinae. Phylogenetic studies using a molecular approach (ROWE and HONEYCUTT, 2002) have connected the genus Kerodon with the genus Hydrochaeris, which includes the capybara (family Hydrochaeridae), and is closely related to the genus Dolichotis of the subfamily
Dolichotinae, whose representative in South America is the Patagonian hare (Dolichotis patagonum).

Behavioral studies carried out in field have reported that this rodent species emerges to forage throughout both day and night, but most of the activity occurs during the day, with peaks of activity at dawn and dusk (CARVALHO, 1969; LACHER, 1981). In line with these observations, an investigation performed under controlled laboratory conditions showed that the rock cavy was active throughout the 24-h day, with peaks during sunrise and sunset, featuring a predominantly crepuscular behavior (SOUSA and MENEZES, 2006). These data suggest that the rock cavy can exhibit optical and retinal adaptations related to light-dark transition, which motivated us to use this animal as a suitable animal model of a regional rodent for studying circadian rhythms. For this, the retinal projections were traced to circadian timing system centers, such as the hypothalamic suprachiasmatic nucleus and the thalamic intergeniculate leaflet (NASCIMENTO Jr., SOUZA, DUARTE et al., 2010b). As well, direct retinal projections to paraventricular (NASCIMENTO Jr., DUARTE, 
SILVA et al., 2008) and mediodorsal (NASCIMENTO Jr., CAVALCANTE, CAVALCANTE et al., 2010a) thalamic nuclei were showed. Studies on targets of retinal projections constituting the primary visual and accessory optic systems, as well as projections to other hypothalamic targets are ongoing. To our knowledge, however, nothing is known about the anatomical features of the rock cavy eye.

Knowledge of eye anatomy, its location in the head and retinal cell distribution have allowed scientists to identify adaptations of each species to its visual field, adaptations which are peculiar to each lifestyle in its ecological niche (COLLIN, 2008). Some rodent species of the Hystricomorpha suborder, such as diurnal agouti and capybara (SILVEIRA, 1985; SILVEIRA, YAMADA and PICANÇO-DINIZ, 1989; PICANÇO-DINIZ, SILVEIRA, CARVALHO et al., 1991), nocturnal paca (SILVEIRA, 1985; SILVEIRA, YAMADA and PICANÇO-DINIZ, 1989), guinea pig (JACOBS and DEEGAN, 1994; PEICHL and GONZÁLEZSORIANO, 1994; PARRY and BOWMAKER, 2002), crepuscular chinchilla (LIMA, MONTIANI-FERREIRA, TRAMONTIN et al., 2010; MÜLLER, MAULER and EULE, 2010) and degus (DETWILER, 1949; CHÁVEZ, BOZINOVIC, PEICHL et al., 2003; JACOBS, CALDERONE, FENWICK et al., 2003), have been used as models for research on various aspects of the visual system. Adaptive mechanisms to the temporal niche are present in the visual system of most vertebrates. These mechanisms involve modifications in the ocular dimensions and design, organization of neural circuits related to the retinal resolution or detection of changes in the levels of luminance (LAND, 2009; LAND and NILSSON, 2012). The quality of the optical system may limit the amount of information that can be made available to the brain since the retina can only encode information that is present in the image (HUGHES, 1977). Therefore, the shape and size of the pupil and focus adjustment are particularly important if an animal has eyes adapted for use under photopic, mesopic or scotopic conditions (MALMSTRÖM and KRÖGER, 2006; HALL and ROSS, 2007).

Taking into account the importance of these ocular features on the temporal niche of each species, the present study investigated morphometric parameters of the rock cavy eye in order to analyze how these features contribute to the gain in visual sensitivity and resolution under conditions of crepuscular lighting. From a comparative point of view, this study contributes to the understanding of the biodiversity of visual adaptations. Previous and future investigations on the visual and circadian timing system of this species are supported.

\section{Materials and Methods}

In this study, young adult rock cavies from rural municipalities in the state of Rio Grande do Norte in the Northeastern region of Brazil were used with the authorization of the Brazilian Institute of Environment and Renewable Natural Resources (IBAMA, SISBIO license no. 22402-1, 2009/12/24). Approval for the experiments was obtained from the local Animal Experimentation Ethics Committee (CEUA-UFRN, protocol no. 015/2009), in compliance with National Institute of Health $(\mathrm{NIH})$ guidelines. All efforts were made to minimize the number of animals and their suffering.

Animals weighing between 338 and $641 \mathrm{~g}$ were used. It was not possible to determine their ages, since all of them were captured from nature. Because of this, we used body weight as a parameter to choose animals neither too young nor too old. After capture, the animals were housed in a room with four wire mesh walls attached to masonry support, ceramic tile ceilings and natural soil floor, with creeping vegetation and rocks to simulate their natural habitat. Thus, the animals were exposed to natural environmental conditions of temperature, humidity and light, with food and water continuously available. All experimental procedures were performed in the Laboratory of Neuroanatomy, Department of Morphology, UFRN. In total, 11 animals ( 2 male and 9 females) were used, from which 22 eyes were obtained. Of these, three ones were used for dissection of the extraocular muscles and were excluded from the measurements. Measurements were taken in 15 fixed and four methanol-dry ice frozen eyes.

The animals were pre-anesthetized with an intramuscular injection of tramadol chloridrate (Cristalia, Itapira, SP, Brazil, $5 \mathrm{mg} / \mathrm{kg}$ ) and, after 15 minutes, anesthetized with an intramuscular injection of ketamine chloridrate (Agener União, Embu-guaçu, SP, Brazil, $100 \mathrm{mg} / \mathrm{kg}$ ) and xylazine (Agener União, Embu-guaçu, SP, Brazil, $5 \mathrm{mg} / \mathrm{kg}$ ). Upon deep anesthesia, with the aid of a digital calliper (Digimess, Ribeirão Preto, SP, Brazil), the palpebral fissure length of each eye was measured, and then the eye was photographed while still inside the orbit to measure pupil diameters. The orientation of each eye was labeled by a small incision in the lateral angle of the cornea.

Still deeply anesthetized, the animals were transcardially perfused, with saline solution in $0.1 \mathrm{M}$ phosphate buffer, $\mathrm{pH}$ $7.4(\mathrm{~PB})$, containing heparin (Hemofol, Cristalia, Itapira, SP, Brazil, $2 \mathrm{ml} / 1000 \mathrm{ml}$ of saline solution), followed by $700 \mathrm{ml}$ of a fixative solution, consisting of $4 \%$ paraformaldehyde in PB solution. In three animals, one of the eyes was kept in the orbita in order to facilitate the dissection of the extraocular muscles. After that, the muscles were identified and photographed.

In all other cases, when the perfusion was finished, the eyes were enucleated and the encephala removed from the skull, by sectioning cranial nerves at their bone emergences, and stored for other studies carried out in the laboratory. Three skulls were skinned and macerated for a study of the bony orbit. The position of the optic nerve in the posterior pole was examined, and, after removal of fat tissue and extraocular muscles, with aid of a digital calliper, the following measures were taken: axial diameter (anteroposterior, AD), from the anterior pole of the cornea to posterior pole of the sclera; equatorial diameter (transversal, ED) of the eye, between the extreme side points of both eyes; and corneal diameter (CD), with the tips of the caliper between the two sides of the cornea-sclera limit.

Next, the lateral incision of the cornea was extended, remaining attached to sclera only on the medial side by about $2 \mathrm{~mm}$. This allowed to keep the orientation of each eye (rightleft) as well as the medial (nasal)-lateral (temporal), dorsalventral orientation. When the window of the cornea was opened, the iris, the pupil aperture and the lens were observed through this aperture. Next, the eyeball was stored in a fixative solution during two hours, and then transferred to PB. 
The internal surface (eyecup) of the posterior hemisphere was also examined, after removal of the iris and lens and the output of the optic nerve (disc of optic nerve) registered.

For the macroscopic exam of internal structures of the eye, four eyes were enucleated previous to fixation, immediately frozen by immersion in methanol and dry ice and sectioned horizontally in a sliding microtome. Throughout this procedure, photographs were taken for posterior analysis of the intraocular dimensions of the lens, corneal diameter, and axial and equatorial diameters of the eye, distances between the cornea and the lens and between the lens and sclera.

Two eyes were immersed in Bouin fixative (aqueous saturated solution of picric acid in formaldehyde and glacial acetic acid) for $24 \mathrm{~h}$, dehydrated in increasing concentrations of ethanol solutions and embedded in paraffin. Five $\mu$ m-thick transversal sections were obtained, which were stained with Hematoxilin-Eosin ( $\mathrm{HE})$, for a later analysis of the layer organization of the retina.

\section{Results}

The rock cavy eye is lateralized and it is housed in a bony orbit, manned by two skin folds, the superior (SP) and inferior (IP) palpebrae, which delimit a palpebral fissure, measuring $10.25 \pm 0.9 \mathrm{~mm}(\mathrm{n}=5$ eyes) (Figure $1 \mathrm{~A})$. The bony orbit has the following skull bone components: frontal, which contributes to superior (ceiling), medial and posterior walls, the maxillar, which takes part in the formation of the medial wall, the temporal, which complements laterally the posterior wall, the sphenoid, which surrounds the optic canal and the lacrimal, which delimits the lacrimal canal. The anterior and ventral (floor) walls are devoid of bony elements. The lateral aperture of the orbit is circumvented ventrally by the zygomatic arch, constituted by the zygomatic process of the temporal bone articulated with the temporal process of the zygomatic bone, and the dorsal border of the zygomatic bone. The anterior wall, opened, is limited laterally by the zygomatic process of the frontal bone articulated with the frontal process of the zygomatic bone. The maxillar process of the zygomatic bone attached to the zygomatic process of the maxillar bone form the ventral limit of the opened anterior wall (Figure 1B-C).

At the anterior pole of the eye, the black iris and the vertical slit shaped pupil was noted through the cornea (Figure 1D). The pupil aperture in the fixed eye measured $3.6 \mathrm{~mm} \times 2.38$ $\mathrm{mm}$ in mean values $(\mathrm{n}=3)$. Both pupil and lens were better visualized after removal of the cornea (Figure $1 \mathrm{E}$ ).

Measurements of ocular dimensions were taken in 15 eyes after fixation of the animals by transcardiac perfusion. These measures allow inferring that the rock cavy eye is

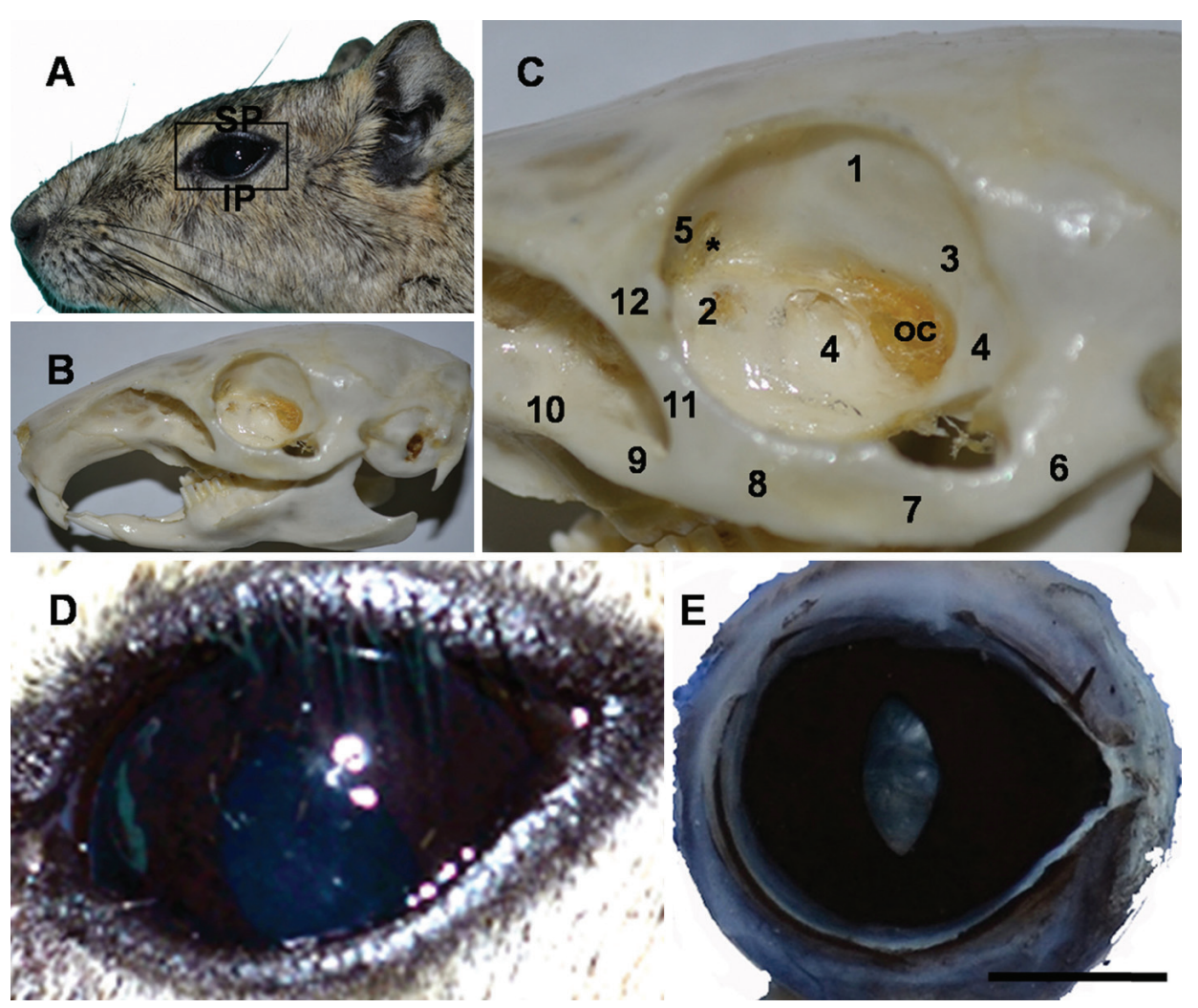

Figure 1. (A) Lateral view of the head of the rock cavy, showing the eye manned by superior (SP) and inferior (IP) palpebrae; (B) Lateral view of the skull, showing the bony orbit. (C) Magnification of the region of the bony orbit, evidencing the participation of the following bones: (1) frontal, (2) maxillar, (3) temporal, (4) sphenoid and (5) lacrimal. Note that ventrolaterally and rostrally the orbit is limited by the zygomatic arc, formed by the zygomatic process of the temporal bone (6) connected to the temporal process of the zygomatic bone (7), the zygomatic bone (8), the maxillar process of the zygomatic bone (9) connected to zygomatic process of the maxillar bone (10) and the frontal process of the zygomatic bone (11) connected to zygomatic process of the frontal bone (12); (D) Magnification of square in A showing the cornea and through this, the dark iris and the slit pupil; (E) The iris and the slit pupil after removal of the cornea. oc, optic canal. Asterisk in C indicates the lacrimal canal aperture. Bar: $24 \mathrm{~mm}$ in A and B, $7 \mathrm{~mm}$ in $\mathrm{C}, 3,4 \mathrm{~mm}$ in $\mathrm{D}$ and $4 \mathrm{~mm}$ in $\mathrm{E}$. 
approximately ellipsoidal shaped, with the antero-posterior (axial) diameter (AD) ranging from $9.65 \mathrm{~mm}$ to $11.47 \mathrm{~mm}$ (average 10.67), equatorial diameter (ED) from $10.39 \mathrm{~mm}$ to $12.65 \mathrm{~mm}$ (average 11.64). The corneal equatorial diameter (EDC) varied from $7.72 \mathrm{~mm}$ to $9.57 \mathrm{~mm}$ (average 8.51). The individual and mean values related to these parameters are listed in the Table 1.

Measurements of axial diameter obtained in those eyes allowed us to estimate the retinal magnification factor (RMF) and the posterior nodal distance of the eye (PND), using the equation proposed by Hughes (1977), based on comparison among several mammalian species, $\mathrm{RMF}=0.011 \mathrm{x}$ eye axial length and PND $=0.63 \mathrm{x}$ eye axial length. Applying these equations to the measurements obtained in the rock cavy eye, we found a value of $118 \mu \mathrm{m} /$ degree of visual angle for RMF and $6.74 \mathrm{~mm}$ for PND.

Around the eye an orbital fascia could be seen, involving the extraocular muscles, which were well identified as the rectus dorsalis $(\mathrm{RD})$, rectus ventralis $(\mathrm{RV})$, rectus medialis $(\mathrm{RM})$, rectus lateralis (RL), obliquus dorsalis (OD) and obliquus ventralis (OV) muscles (Figure $2 \mathrm{~A}-\mathrm{B}$ ).

At the posterior pole, we identified the emergence of the optic nerve trunk, positioned eccentrically in a temporal and ventral direction (Figure 3A). After removal of the lens, the examination of the retina in situ does not allow identification by the naked eye of any tissue depression or thickening, which might suggest the presence of some retinal specialization, or lucidum tapetum (Figure $3 \mathrm{~B}$ ), which in some other animals can be observed without the use of an optical microscope. Retinal vessels were not observed either, which characterize an anangiotic retina. Figure $3 \mathrm{C}$ illustrates the retina after dissected from the eyecup and removal of the pigment epithelium.

After hemissectomy of the eyes which had been freshly frozen in methanol with dry ice, it was possible to better visualize the curvature of the cornea and the asymmetrical shape of the lens, with curvature more pronounced in its posterior aspect. Measurements of axial diameter of the cornea and axial and equatorial diameters of the lens through the horizontal axis were taken in ocular sections from four animals. The maximum axial and equatorial diameters of the lens were on average $5.39 \pm 0.03 \mathrm{~mm}$ and $6.77 \pm 0.24 \mathrm{~mm}$, respectively, obtained in the dorsal position to the point of emergence of the optic nerve, coincident with the maximum eye axial diameter $(11.99 \pm 0.518 \mathrm{~mm})$. At the same level, the equatorial curvature of the cornea was on average $8.71 \pm 0.84 \mathrm{~mm}$. The distance between the anterior surface of the cornea and the anterior aspect of the lens was $2.21 \pm 0.27 \mathrm{~mm}$ and the distance from the posterior aspect of the lens to the posterior surface of the sclera was

Table 1. Eye rock cavy parameters.

\begin{tabular}{|c|c|c|c|c|c|c|c|c|c|}
\hline $\begin{array}{c}\text { Animal } \\
\text { (Fixed } \\
\text { eyes) }\end{array}$ & $\begin{array}{c}\text { Weight } \\
\text { (g) }\end{array}$ & $\begin{array}{l}\mathrm{AD} \\
\mathrm{mm}\end{array}$ & $\begin{array}{l}\mathrm{ED} \\
\mathrm{mm}\end{array}$ & $\begin{array}{c}\text { EDC } \\
\mathrm{mm}\end{array}$ & $\begin{array}{c}\mathrm{ADL} \\
\mathrm{mm}\end{array}$ & $\begin{array}{c}\text { EDL } \\
\mathrm{mm}\end{array}$ & $\begin{array}{c}\text { C-Ld } \\
\mathrm{mm}\end{array}$ & $\begin{array}{c}\text { L-Ed } \\
\mathrm{mm}\end{array}$ & $\begin{array}{c}\mathrm{LF} \\
\%\end{array}$ \\
\hline $1 \mathrm{RE}$ & 363 & 9.65 & 10.39 & 7.80 & & & & & 56 \\
\hline $2 \mathrm{RE}$ & 503.5 & 11.28 & 12.54 & 8.97 & & & & & 48 \\
\hline $3 \mathrm{RE}$ & 596.5 & 10.76 & 12.62 & 8.57 & & & & & 50 \\
\hline $4 \mathrm{RE}$ & 603 & 10.69 & 11.35 & 7.72 & & & & & 50 \\
\hline $5 \mathrm{RE}$ & 467 & 10.74 & 11.46 & 8.76 & & & & & 50 \\
\hline $6 \mathrm{RE}$ & 558.5 & 10.93 & 11.97 & 9.56 & & & & & 49 \\
\hline $1 \mathrm{LE}$ & 363 & 9.66 & 10.42 & 7.72 & & & & & 56 \\
\hline $2 \mathrm{LE}$ & 503.5 & 11.35 & 12.24 & 8.99 & & & & & 47 \\
\hline $3 \mathrm{LE}$ & 596.5 & 11.47 & 12.65 & 8.62 & & & & & 47 \\
\hline $4 \mathrm{LE}$ & 603 & 10.31 & 11.43 & 7.95 & & & & & 52 \\
\hline $5 \mathrm{LE}$ & 467 & 10.92 & 11.59 & 8.63 & & & & & 49 \\
\hline $6 \mathrm{LE}$ & 558.5 & 10.47 & 11.23 & 9.57 & & & & & 51 \\
\hline $7 \mathrm{RE}$ & 387 & 11.04 & 11.61 & 8.26 & & & & & 49 \\
\hline $8 \mathrm{LE}$ & 338 & 10.21 & 11.36 & 8.24 & & & & & 52 \\
\hline $9 \mathrm{LE}$ & 377.5 & 10.52 & 11.71 & 8.30 & & & & & 51 \\
\hline Mean & 485.7 & 10.67 & 11.64 & 8.51 & & & & & 50.0 \\
\hline SD & 99.06 & 0.55 & 0.69 & 0.60 & & & & & 2.72 \\
\hline \multicolumn{10}{|c|}{ Animal (eyes frozen in dry ice) } \\
\hline $8 \mathrm{RE}$ & 338 & 11.63 & 12.38 & 8.16 & 5.36 & 6.57 & 1.89 & 6.59 & 46 \\
\hline $9 \mathrm{RE}$ & 377.5 & 11.61 & 12.35 & 8.03 & 5.38 & 6.64 & 2.19 & 5.58 & 46 \\
\hline $10 \mathrm{LE}$ & 641 & 12.72 & 13.28 & 9.87 & 5.43 & 7.12 & 2.56 & 5.87 & 43 \\
\hline $11 \mathrm{LE}$ & 600 & 12.01 & 12.68 & 8.78 & 5.39 & 6.76 & 2.19 & 5.98 & 45 \\
\hline Mean & 489 & 11.99 & 12.67 & 8.71 & 5.39 & 6.77 & 2.21 & 6.01 & 45 \\
\hline SD & 153 & 0.518 & 0.431 & 0.84 & 0.03 & 0.24 & 0.27 & 0.42 & 1.41 \\
\hline
\end{tabular}

RE, Right eye; LE, Left eye; AD, Eye axial diameter axial; ED, Eye equatorial diameter; EDC, Corneal equatorial diameter; ADL, Lens axial diameter; EDL, Lens equatorial diameter; C-Ld, Distance between the cornea and the anterior aspect of the lens; L-Ed, Distance between the posterior aspect of the lens and the sclera; LF, Fraction of the lens relative to eye axial diameter. Animals 1 to 7 only fixed eyes were used and are utilized in other studies of the lab. The left eye of the animal 7 and the right eyes of the animals 10 and 11 were used for dissection of the extraocular muscles. Animals 7 to 11 had only one eye dry ice frozen and the other one fixed. 

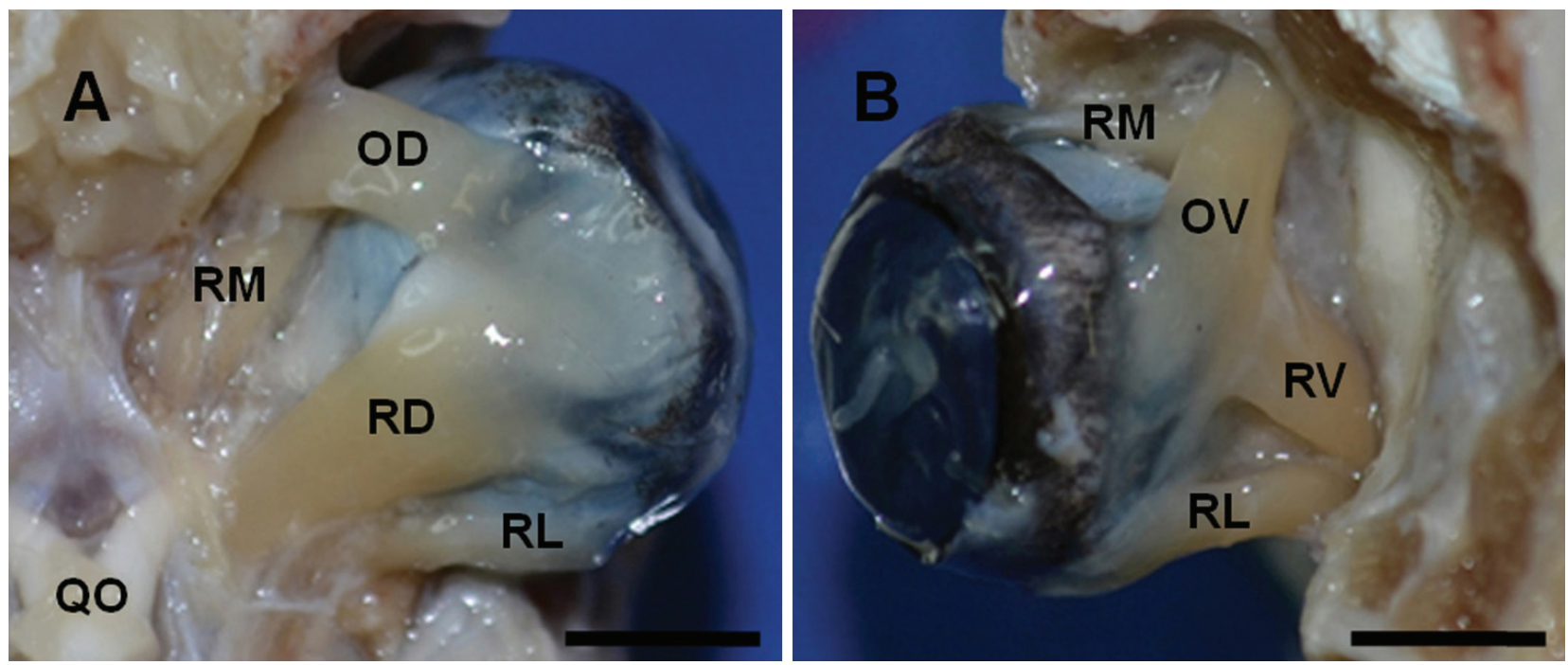

Figure 2. Rock cavy eye partially housed in the orbit, with the extraocular muscles dissected. (A) Dorsal view showing rectus medialis (RM), rectus dorsalis (RD), rectus lateralis $(\mathrm{RL})$ and obliquus dorsalis (OD) muscles. OC, optic chiasm. (B) Ventral view showing RM, RL, rectus ventralis $(\mathrm{RV})$ and obliquus ventralis $(\mathrm{OV})$ muscles. Bar: $5 \mathrm{~mm}$.
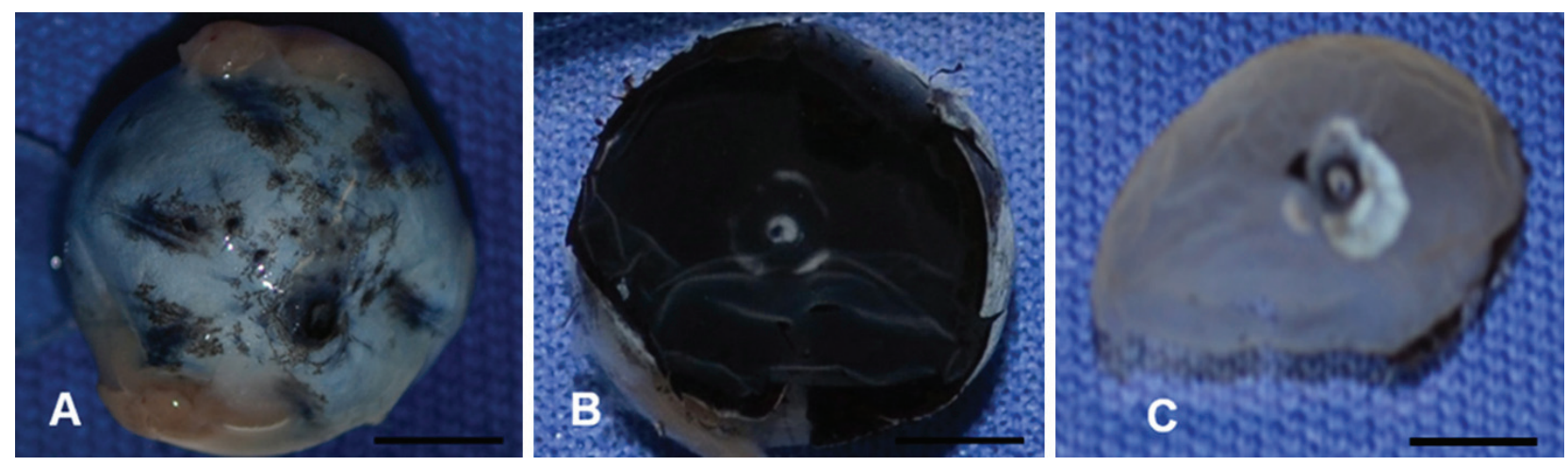

Figure 3. (A) Posterior view of the right eye, showing the emergence of the optic nerve; (B) Inner view of the posterior segment of the eye, showing the disc of the optic nerve, $(\mathrm{C})$ The retina after dissected from the eyecup and removal of the pigment epithelium. Bar: $5 \mathrm{~mm}$

$6.01 \pm 0.42 \mathrm{~mm}$. Figure 5 illustrates images of eye sections at the level of optic nerve emergence (Figure $4 \mathrm{~A}$ ) and at its longest axis (Figure 4B). The mean value of the eye axial diameter obtained in four sectioned eyes $(11.99 \pm 0.518$ $\mathrm{mm}$ ) is similar to that obtained after enucleation immediately after fixation by perfusion as listed in Table 1. Fraction of the lens relative to eye axial diameter (LF) obtained after hemissectomy provided a mean value of $45 \pm 1.41 \%$. Applying the mean lens axial diameter estimated after eye hemissectomy to eye axial length obtained immediately after perfusion, it was found a mean value of $50 \pm 2.72 \%$ (Table 1 ).

Transversal sections of the rock cavy retina stained with hematoxilin/eosin ( $\mathrm{HE})$, showed the laminar organization of this tissue, characterized by the presence of layer of outer segments of photoreceptors, outer (ONL) and inner (INL) nuclear and plexiform layers, ganglionar cell layer (CGL) and optic nerve fiber layer. The thickness of these layers varied according to retinal eccentricity. Figure 5 illustrates retinal transversal sections at the far periphery and central eccentricities. As can be noted, while at the extreme periphery (Figure 5A), the ONL and INL exhibited around 3 and 2 cell rows, respectively, in the central region (Figure 5B), in the same layers, 5 and 3 cell rows respectively could be observed. In the GCL only one cell row was observed at both the central or far peripheral retinal regions.

\section{Discussion}

Evolutionary attempts to modify the ocular structure may appear relatively quickly in the geologic time span, suggesting that the eyes themselves are highly responsive in modifying structure according to environmental pressures. A plethora of visual adaptations and solutions to ecological requirements for special niches provide evidence that optic physiology is relatively plastic. Adaptive mechanisms to the temporal niche are present in the visual systems of most vertebrates (LAND, 2009, 2012; LAND and NILSSON, 2012). Present data show that the rock cavy eye has a roughly ellipsoidal shape with a slight predominance of the equatorial on the axial diameter, similar to what has been described about other rodent species of the suborder Hystricomorpha, such as the agouti (Dasyprocta aguti), paca (Cuniculus paca), capybara (Hydrochaerus hydrochaeris) (SILVEIRA, 

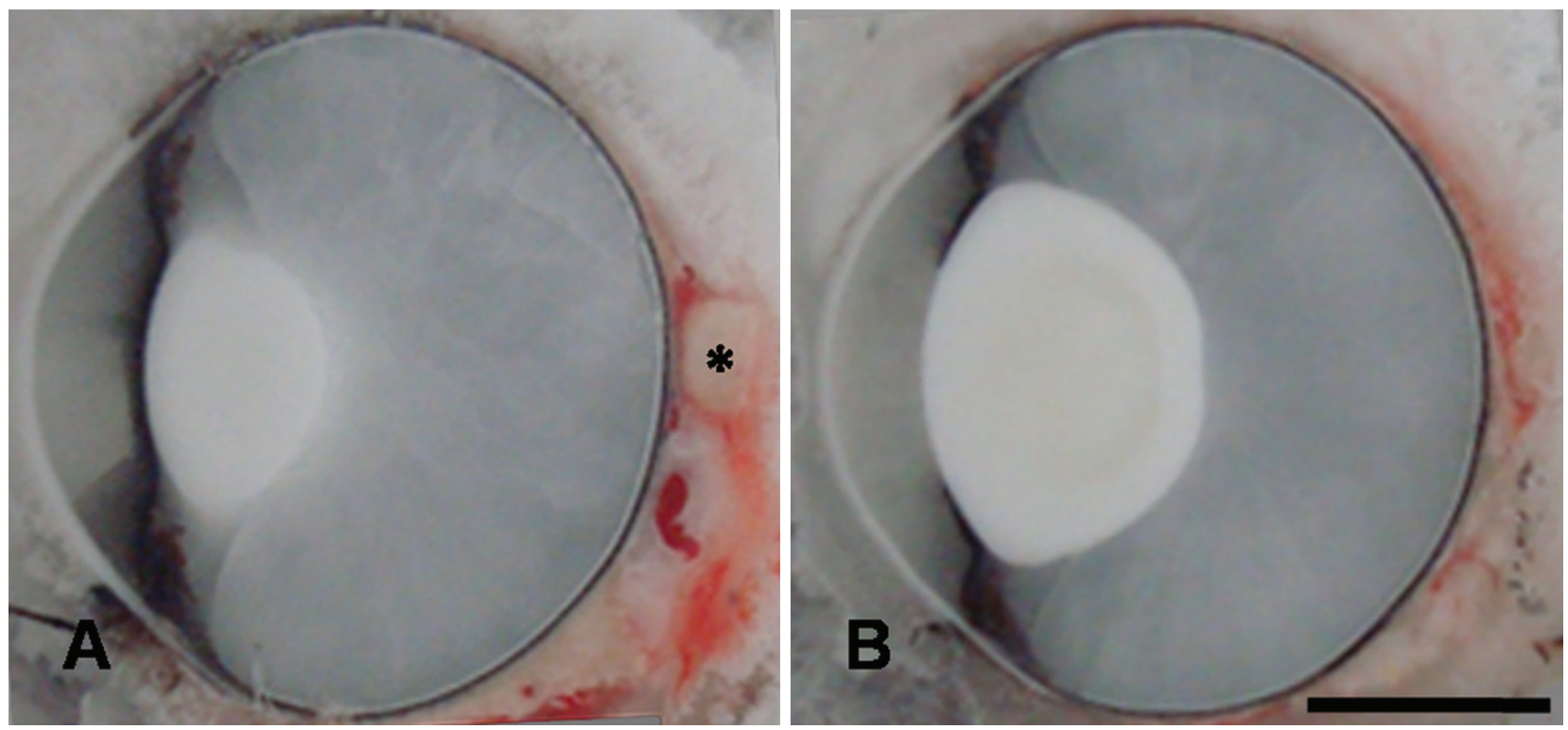

Figure 4. Images of sections of the dry ice frozen eye at level of (A) emergence of the optic nerve (asterisk) and (B) at the longest axis of the eye. Bar: $4.25 \mathrm{~mm}$.
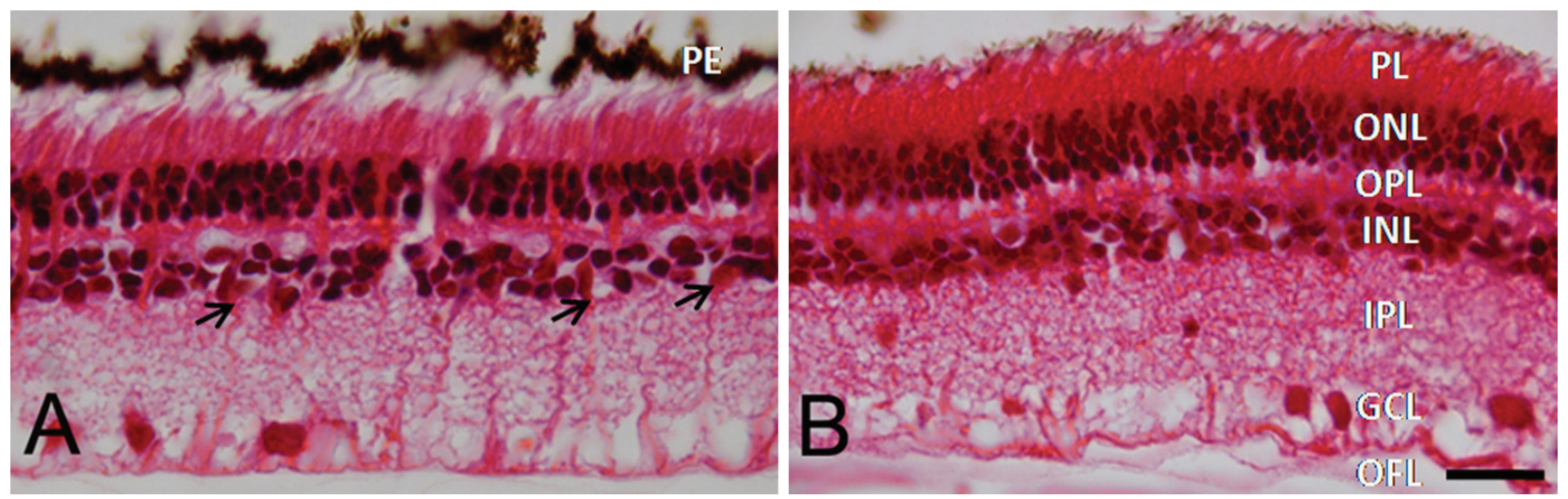

Figure 5. Transversal sections of the rock cavy retina stained with hematoxilin-esosin (HE) at (A) extreme periphery and (B) central region. $\mathrm{PE}=$ pigment epithelium, $\mathrm{PL}=$ photoreceptor layer, $\mathrm{ONL}=$ outer nuclear layer, $\mathrm{OPL}=$ outer plexiform layer, $\mathrm{INL}=\mathrm{inner}$ nuclear layer, IPL=inner plexiform layer, GCL=ganglion cells layer, $\mathrm{OFL}=$ optic nerve fibers layer. Arrows in A point out Müller cells. Bar: $20 \mu \mathrm{m}$.

1985; SILVEIRA, YAMADA and PICANÇO-DINIZ, 1989; PICANÇO-DINIZ, SILVEIRA, CARVALHO et al., 1991; ROCHA, AHNELT, PEICHL et al., 2009), guinea pig (Cavia porcellus) (JACOBS and DEEGAN, 1994; PEICHL and GONZÁLEZ-SORIANO, 1994; PARRY and BOWMAKER, 2002), chinchilla (Chinchilla lanigera) (LIMA, MONTIANI-FERREIRA, TRAMONTIN et al., 2010; MÜLLER, MAULER and EULER, 2010) and degus (Octodon degus) (CHÁVEZ, BOZINOVIC, PEICHL et al., 2003; JACOBS, CALDERONE, FENWICK et al., 2003), with which the rock cavy has close phylogenetic relationships.

The axial length of the eye is closely related to the focal length, which is equivalent to PND, estimated as two-thirds of the axial length in vertebrates. More precisely, from comparative ophthalmoscopic studies, the focal length can be calculated by multiplying the axial length by the factor 0.665 (MURPHY and HOWLAND, 1987). Applying this formula to the rock cavy, considering the mean axial length estimated as $10.7 \mathrm{~mm}$, a focal length can be calculated, whose mean value is $7.11 \mathrm{~mm}$. Using the empirical equation of Hughes (1977) we also estimated the focal length of the rock cavy eye as $6.74 \mathrm{~mm}$, similar to that obtained by the Murphy and Howland (1987) equation. In other hystricomorpha species, such as the agouti, paca and capybara, which exhibit eye axial lengths $(15.68 \mathrm{~mm}, 18.46 \mathrm{~mm}$ and $22.30 \mathrm{~mm}$ respectively) longer than the rock cavy, the focal length corresponds to $9.88 \mathrm{~mm}$ (agouti), $11.63 \mathrm{~mm}$ (paca) and $14.05 \mathrm{~mm}$ (capybara) (SILVEIRA, 1985). The focal length influences the size of the image formed on the retina and hence it is related to the amount of information that reaches the brain. The RMF is expressed in millimeters of retina per degree of visual angle. This factor and the photoreceptor or ganglion cell density are directly related to retinal resolution power. The maximal retinal sampling frequency can be obtained by the following equation: $v c=(\mathrm{RMF} . \sqrt{ } d M A X) / 1000$ (where $v c$ is the maximum sampling frequency and $d M A X$ is the 
maximum cell density). Thus, the gain in visual resolution can be obtained by a decrease of the distance among the photoreceptors or by an increase in their density, and also by increase in eye size (HUGHES, 1977; LAND, 2012). Using the empirical equation proposed by Hughes (1977), we estimated a RMF equivalent to $118 \mu \mathrm{m} /$ degree for the rock cavy, which is inferior to those estimated for agouti (164 $\mu \mathrm{m} /$ degree), paca (203 $\mu \mathrm{m} /$ degree) and capybara (245 $\mathrm{\mu m} /$ degree) (SILVEIRA, 1985). Although the main characteristics of the eye may be preserved in the phylogeny, the history of each family or genus adds eye features that are more specifically related to the lifestyle within a temporal niche than with the relationship among the species. The axial length of the eye per se is not the most important parameter for defining the suitability of an eye to a pattern of animal activity. The axial dimension and the curvature of the lens relative to eye size must be considered, because these parameters influence the rate of retinal illumination (HUGHES, 1977; LAND, 2009).

In diurnal animals, the optic design favors a gain in resolution, given a greater PND and a smaller axial thickness of the lens. In this case, there is a loss in sensitivity considering that the index of retinal illumination is inversely proportional to PND (HUGHES, 1977; LAND and NILSSON, 2012). On the other hand, in some nocturnal animals, an increase in the eye size and RMF improve retina sensitivity without reducing its resolution when compared with eyes of diurnal animals. In this case, the increase of the retinal illumination rate is favored by a thickener lens and the occupation of a larger area inside the eye. In the rock cavy, the $4.8 \mathrm{~mm}$ axial diameter of the lens corresponds to around $45 \%$ of the eye axial length. This value is compatible with an eye adapted to an environment which is predominantly crepuscular, when compared to values obtained in hystricomorpha rodents of diurnal habits, such as the agouti (39\%) and capybara (33\%) (SILVEIRA, 1985), crepuscular habits, as chinchilla $48 \%$ (LIMA, MONTIANI-FERREIRA, TRAMONTIN et al., $2010)$ and those with nocturnal habits, such as the paca (51\%) (SILVEIRA, 1985; SILVEIRA, YAMADA and PICANÇODINIZ, 1989). When compared to other typically nocturnal mammals, the value calculated for the rock cavy is lower than that described for the mouse, rat, opossum, bush baby and cat, which vary between 60 and 80\% (HUGHES, 1977; LAND and NILSSON, 2012).

It should be emphasized that the rock cavy eye, as other Hystricomorpha species, such as the degus (DETWILER, 1949) and chinchilla (LIMA, MONTIANI-FERREIRA, TRAMONTIN et al., 2010) has a slit pupil. The value of $3.6 \mathrm{~mm}$ found to the major axis of this slit pupil is similar to what has been described in the agouti, in which, under extreme photopic conditions, the pupil is around $3 \mathrm{~mm}$ at its greatest axis diameter. In the paca, when fully contracted, the slit pupil perpendicular to the eyelid line, measures about $1.43 \mathrm{~mm}$ length and $0.48 \mathrm{~mm}$ width (SILVEIRA, 1985; SILVEIRA, YAMADA and PICANÇO-DINIZ, 1989). According to the literature, the slit pupil allows a better use of the total lens diameter even in bright light (SMITH and ATCHISON, 1997; MALMSTRÖM and KRÖGER, 2006). Additionally, the slit pupil is often associated with multifocal optical systems, in which the lens is provided with concentric zones of different refractive powers for each wavelength. The combination of a slit pupil with a multifocal lens has been described for a large number of vertebrates (MALKKI and KRÖGER, 2005; MALMSTRÖM and KRÖGER, 2006; KARPESTAM, GUSTAFSSON, SHASHAR et al., 2007; GUSTAFSSON, COLLIN and KRÖGER, 2008; HANKE, KRÖGER, SIEBERT et al., 2008; LIND, KELBER and KRÖGER, 2008; KRÖGER, FRITSCHES and WARRANT, 2009) as a characteristic that favors chromatic perception (MALMSTRÖM and KRÖGER, 2006). The multifocality of the lens is a compensation to reduce longitudinal chromatic aberration. Animal eyes that are primarily used under low-light conditions, for example, usually have optical systems of short depth of focus, so that chromatic defocus may lead to considerable blurring of the images. For maximum light-gathering ability, the eyes of nocturnal and crepuscular vertebrates have pupils that are large relative to the focal lengths of the optical systems. A multifocal lens combined with slit pupil was also described in the eye of few vertebrates of monochromatic vision (MALMSTRÖM and KRÖGER, 2006). Although we did not perform refractive measurements in the rock cavy eye, it is possible that this species is endowed with a multifocal lens, compatible with slit pupil and color vision. In line with this hypothesis, recent evidence of our laboratory has indicated that the rock cavy has a rod-dominated retina, but contains cones sensitive to short (blue, S), middle and long (green-red) wavelengths distributed along all this tissue (unpublished data).

\section{Conclusion}

Thus, we can conclude that, from a comparative point of view, the rock cavy eye has general similarities to the eyes of other rodents of the suborder Hystricomorpha. However, peculiarities inherent in the shape and dimensions of its optical elements enable it to have a greater sensitivity to light, at the expense of image sharpness, if compared to the diurnal species. Taken together, these results are compatible with a vision suitable to mesopic conditions, reinforcing previous data indicating that this animal has a predominantly crepuscular activity pattern.

Acknowledgments: This work was supported by The National Council for Scientific and Technological Development (CNPq), Coordination for High Level Staff Improvement (CAPES), Research and Projects Financing (FINEP), and The Foundation for the Support of Research of the State of Rio Grande do Norte (FAPERN), Brazil.

\section{References}

CARLETON, MD. and MUSSER, GG. Order rodentia. In WILSON, DE. and REEDER, DM. (Eds.). Mammal species of the World: a taxonomic and geographic reference. Baltimore: John Hopkins University Press, 2005. p. 745-752.

CARVALHO, JCM. Notas da viagem de um zoólogo à região das caatingas e áreas limitrofes. Fortaleza: Imprensa Universitária do Ceará, 1969. p. 131-134.

CHÁVEZ, AE., BOZINOVIC, F., PEICHL, L. and PALACIOS, AG. Retinal spectral sensitivity, fur coloration, and urine reflectance in the genus Octodon (Rodentia): implications for visual ecology. Investigative Ophthalmology and Visual Science, 2003, vol. 44, n. 5, p. 2290-2296. http://dx.doi.org/10.1167/iovs.02-0670 
COLLIN, SP. A web-based archive for topographic maps of retinal cell distribution in vertebrates. Clinical and Experimental Optometry, 2008, vol. 91, n. 1, p. 85-95. PMid:18045254. http:// dx.doi.org/10.1111/j.1444-0938.2007.00228.x

DETWILER, SR. The eye of the chinchilla (C. lanigera). Journal of Morphology, 1949, vol. 84, n. 1, p. 123-144. PMid:18108873. http://dx.doi.org/10.1002/jmor.1050840106

GUSTAFSSON, OSE., COLLIN, SP. and KRÖGER, RHH. Early evolution of multifocal for well-focused colour vision in vertebrates. The Journal of Experimental Biology, 2008, vol. 211, p. 1559-1564. PMid:18456882. http://dx.doi.org/10.1242/jeb.016048

HALL, MI. and ROSS, CF. Eye shape and activity pattern in birds. Journal of Zoology, 2007, vol. 271, n. 4, p. 437-444. http://dx.doi. org/10.1111/j.1469-7998.2006.00227.x

HANKE, FD., KRÖGER, RHH., SIEBERT, U. and DEHNHARDT, G. Multifocal lenses in a monochromat: the harbor seal. The Journal of Experimental Biology, 2008, vol. 211, p. 33153322. PMid:18840666. http://dx.doi.org/10.1242/jeb.018747

HUGHES, A. The topography of vision in mammals of contrasting life style: Comparative optics and retinal organization. In CRESCITELLI, F. (Ed.). Handbook of sensory physiology, VII/5: the visual system in vertebrates. Berlin: Springer-Verlag, 1977. p. 613 656.

JACOBS, GH., CALDERONE, JB., FENWICK, JA., KROGH, $\mathrm{K}$. and WILLIAMS, GA. Visual adaptations in a diurnal rodent, Octodon degus. Journal of Comparative Physiology A, 2003, vol. 189, n. 5, p. 347-361. PMid:12679876.

JACOBS, GH. and DEEGAN, JF. Spectral sensitivity, photopigments, and color vision in the guinea pig (Cavia porcellus). Behavioral Neuroscience, 1994, vol. 108, n. 5, p. 993-1004. PMid:7826522. http://dx.doi.org/10.1037/0735-7044.108.5.993

KARPESTAM, B., GUSTAFSSON, J., SHASHAR, N., KATZIR, G. and KRÖGER, RHH. Multifocal lenses in coral reef fishes. The Journal of Experimental Biology, 2007, vol. 210, n. 16, p. 29232931. PMid:17690241. http://dx.doi.org/10.1242/jeb.002956

KRÖGER, RHH., FRITSCHES, KA. and WARRANT, EJ. Lens optical properties in the eyes of large marine predatory teleosts. Journal of Comparative Physiology A, 2009, vol. 195, p. 175-182. PMid:19048260. http://dx.doi.org/10.1007/s00359-008-0396-1

LACHER, TE. The comparative social behavior of Kerodon rupestris and Galea spixii and the evolution of behavior in the Caviidae. Bulletin of Carnegie Museum of Natural History, 1981, n. 17, p. 1-71.

LAND, MF. Vision, eye movements, and natural behaviour. Visual Neuroscience, 2009, vol. 26, n. 1, p. 51-62. PMid:19203425. http://dx.doi.org/10.1017/S0952523808080899

LAND, MF. The operation of the visual system in relation to action. Current Biology, 2012, vol. 22, n. 18, p. R811-R817. PMid:23017999. http://dx.doi.org/10.1016/j.cub.2012.06.049

LAND, MF. and NILSSON, DE. Animal eyes. Oxford: Oxford University Press, 2012. 271 p.

LIMA, L., MONTIANI-FERREIRA, F., TRAMONTIN, M., SANTOS, LL., MACHADO, M., LANGE, RR. and ABIL RUSS, $\mathrm{HH}$. The chinchilla eye: morphologic observations, echobiometric findings and reference values for selected ophtalmic diagnostic tests. Veterinary Opthalmology, 2010, vol. 13, Supplement 1, p. 14-25. PMid:20840086. http://dx.doi.org/10.1111/j.14635224.2010.00785.x

LIND, OE., KELBER, A. and KRÖGER, RHH. Multifocal optical systems and pupil dynamics in birds. The Journal of Experimental Biology, 2008, vol. 211, p. 2752-2758. PMid:18723531. http:// dx.doi.org/10.1242/jeb.018630
MALKKI, P. and KRÖGER, RHH. Visualization of chromatic aberration of fish lenses by multiple focal lengths. Journal of Optics A: Pure and Applied Optics, 2005, vol. 7, n. 11, p. 691-700. http:// dx.doi.org/10.1088/1464-4258/7/11/012

MALMSTRÖM, T. and KRÖGER, RHH. Pupil shapes and lens optics in the eyes of terrestrial vertebrates. The Journal of Experimental Biology, 2006, vol. 209, p. 18-25. PMid:16354774. http://dx.doi.org/10.1242/jeb.01959

MÜLLER, K., MAULER, DA., and EULE, JC. Reference values for selected ophthalmic diagnostic tests and clinical characteristics of chinchilla eyes (Chinchilla lanigera). Veterinary Ophtalmology, 2010, vol. 13, Supplement 1, p. 29-34. PMid:20840088. http://dx.doi. org/10.1111/j.1463-5224.2010.00801.x

MURPHY, CJ. and HOWLAND, HC. The optics of comparative ophthalmology. Vision Research, 1987, vol. 27, n. 4, p. 599-607. http://dx.doi.org/10.1016/0042-6989(87)90045-9

NASCIMENTO Jr., ES., DUARTE, RB., SILVA, SF., ENGELBERTH, RCGJ., TOLEDO, CAB., CAVALCANTE, JS. and COSTA, MSMO. Retinal projections to the thalamic paraventricular nucleus in the rock cavy (Kerodon rupestris). Brain Research, 2008, vol. 1241, p. 56-61. PMid:18817760. http:// dx.doi.org/10.1016/j.brainres.2008.09.017

NASCIMENTO Jr., ES., CAVALCANTE, JS., CAVALCANTE, JC. and COSTA, MSMO. Retinal afferents to the thalamic mediodorsal nucleus in the rock cavy (Kerodon rupestris). Neuroscience Letters, 2010a, vol. 475, n. 1, p. 38-43. PMid:20338219. http://dx.doi. org/10.1016/j.neulet.2010.03.040

NASCIMENTO Jr., ES., SOUZA, APM., DUARTE, RB., MAGALHÃES, MAF., SILVA, SF., CAVALCANTE, JC., CAVALCANTE, JS. and COSTA, MSMO. The suprachiasmatic nucleus and the intergeniculate leaflet in the rock cavy (Kerodon rupestris): retinal projections and immunohistochemical characterization. Brain Research, 2010b, vol. 1320, p. 3446. PMid:20096673. http://dx.doi.org/10.1016/j. brainres.2010.01.034

PARRY, JWL. and BOWMAKER, JK. Visual pigment coexpression in guinea pig cones: a microspectrophotometric study. Investigative Ophthalmology and Visual Science, 2002, vol. 43, n. 5, p. 1662 1665. PMid:11980888.

PEICHL, L. and GONZÁLEZ-SORIANO, J. Morphological types of horizontal cell in rodent retinae: a comparison of rat, mouse, gerbil, and guinea pig. Visual Neuroscience, 1994, vol. 11, n. 3, p. 501-517. PMid:8038125. http://dx.doi.org/10.1017/ S095252380000242X

PICANÇO-DINIZ, CW., SILVEIRA, LCL., CARVALHO, MSP. and OSWALDO-CRUZ, E. Contralateral visual field representation in area 17 of the cerebral cortex of the agouti: a comparison between the cortical magnification factor and retinal ganglion cell distribution. Neuroscience, 1991, vol. 44, n. 2, p. 325-333. http:// dx.doi.org/10.1016/0306-4522(91)90057-U

ROBERTS, ME., MALINIAK, E. and DEAL, M. The reproductive biology of the rock cavy, Kerodon rupestris in captivity: a study of reproductive adaptation in a tropic specialist. Mammalia, 1984, vol. 48, n. 2 , p. $253-266$.

ROCHA, FAF., AHNELT, PK., PEICHL, L., SAITO, CA., SILVEIRA, LCL. and LIMA, SMA. The topography of cone photoreceptors in the retina of a diurnal rodent, the agouti (Dasyprocta aguti). Visual Neuroscience, 2009, vol. 26, n. 2, p. 167-175. PMid:19250601. http://dx.doi.org/10.1017/ S095252380808098X

ROWE, DL. and HONEYCUTT, RL. Phylogenetic relationships, ecological correlates, and molecular evolution within the cavioidea (Mammalia, Rodentia). Molecular Biology and Evolution, 2002, vol. 19, n. 3, p. 263-277. PMid:11861886. http://dx.doi. org/10.1093/oxfordjournals.molbev.a004080 
SILVEIRA, LCL. Organização do sistema visual de roedores da Amazônia: óptica ocular e distribuição das células ganglionares retinianas. Rio de Janeiro: Instituto de Biofísica; Universidade Federal do Rio de Janeiro, 1985. [Tese de Doutorado].

SILVEIRA, LC., YAMADA, ES. and PICANÇO-DINIZ, CW. Displaced horizontal cells and biplexiform horizontal cells in the mammalian retina. Visual Neuroscience, 1989, vol. 3, n. 5, p. 483-488. PMid:2487119. http://dx.doi.org/10.1017/ S0952523800005988
SMITH, G. and ATCHISON, DA. The eye and visual optical instruments. New York: Cambridge University Press, 1997.

SOUSA, RA. and MENEZES, AAL. Circadian rhythms of motor activity of the Brazilian rock cavy (Kerodon rupestris) under artificial photoperiod. Biological Rhythm Research, 2006, vol. 37, n. 5, p. 443-450. http://dx.doi.org/10.1080/09291010600869836

Received August 18, 2013

Accepted February 6, 2014 